\title{
POTASSIUM AND SODIUM RESTRICTION IN THE NORMAL HUMAN ${ }^{1}$
}

\author{
BY RICHARD A. WOMERSLEY ${ }^{2}$ AND JAMES H. DARRAGH 3 \\ (From the Department of Medicine, Yale University School of Medicine, New Haven, Conn.)
}

(Submitted for publication October 19, 1954 ; accepted November 24, 1954)

Restriction of potassium intake leads to depletion of body potassium, chiefly as a result of losses of potassium in the urine (1-3). The ability of the kidney to conserve potassium has been variously assessed. Tarail and Elkinton (4) considered the renal mechanism for potassium conservation to be relatively inefficient, whereas Fourman (5) has demonstrated a $U / P$ ratio of less than 1.0 in the normal human. Depletion of body potassium may be associated with hypokalemic alkalosis (1), shifts of sodium into potassium depleted cells (6) and retention of sodium in the extracellular phase with expansion of the extracellular fluid $(1,2)$.

The following experiments were designed to study the effects on the composition of the serum and urine, in normal humans, of 1) restricted potassium intake alone, and 2) restriction of sodium and potassium concurrently. External balances of water and electrolytes were observed, and internal balances of sodium, potassium, and water were calculated. Clearances of endogenous creatinine were calculated.

\section{EXPERIMENTAL PROCEDURES AND METHODS}

Three studies were carried out on two normal male subjects. Studies $\mathrm{RW}^{\mathbf{1}}$ and $\mathrm{RW}^{\mathbf{2}}$ were similar in design. Each was divided into an Initial period when sodium and potassium intakes were maintained at normal levels, a Depletion $(K)$ period when potassium intake was restricted, a Depletion ( $\mathrm{Na}$ and $\mathrm{K}$ ) period when both sodium and potassium intakes were restricted (in $\mathrm{RW}^{1}$ $9 \mathrm{gm}$. of ammonium chloride were administered on the last day of this period), and a Reloading period when sodium and potassium were returned to the diet. Study JD was divided into an Initial period, a Depletion ( $\mathrm{Na}$ and $K$ ) period when both sodium and potassium intakes were restricted, and a Depletion (K) period when so-

\footnotetext{
1 Aided by a Grant from the U. S. Public Health Service.

2 Present address : Department of Medicine, Queen's University of Belfast, Belfast, Northern Ireland.

3 Captain, Medical Corps, U.S.A.R.
}

dium was restored to the diet but potassium restriction was continued.

Blood samples were drawn, without stasis, under oil at the beginning and end of each period and at intermediate points. After clotting, they were centrifuged for 15 minutes and the serum drawn off. Urine was collected in 24-hour periods under mineral oil and toluol and kept refrigerated until analyzed. Stools for each period were collected, carmine red markers being used, and preserved by the addition of sulfuric acid. The subjects were weighed daily at 9 a.m. in the postabsorptive state.

Serum was analyzed for sodium, potassium, inorganic phosphorus, carbon dioxide, chloride, total proteins, and creatinine. Urine was analyzed for sodium, potassium, ammonia, titratable acid, chloride, phosphorus, carbon dioxide, $\mathrm{pH}$, creatinine, and nitrogen. Feces were analyzed for sodium, potassium, chloride, and nitrogen.

The basic diet for study RW' was Mead Johnson's Laboratory Product No. 4124. This product contains the solids from milk, rendered low in sodium and potassium, with added Dextri-maltose 8 . Four hundred and fifty-four grams of this product, which contained $15 \mathrm{mEq}$. of potassium, were made up in distilled water for each day's basic diet. In order to lower this figure for potassium, the solution was treated with an ion-exchange resin in the ammonium cycle (except on the last three study days) and an aliquot was analyzed for sodium, potassium, and nitrogen. By this means the basic dietary potassium intake was reduced to between 2 and $3 \mathrm{mEq}$. per day.

The basic diet for studies $\mathrm{RW}^{2}$ and JD was Mead Johnson's Laboratory Product No. 412A.4 This is similar to Product No. 412 except that $454 \mathrm{gm}$. provided approximately $1 \mathrm{mEq}$. of potassium and $1 \mathrm{mEq}$. of sodium. Both diets were adequate in calories and nitrogen and provided $8 \mathrm{mEq}$. of chloride per day. In all studies supplements of sodium and potassium, as the chloride salts, were added to the basic diets in the Initial periods and in the other periods, as indicated previously, to give the daily intakes indicated in Table $\mathrm{I}$. Additional calcium chloride was given in study $\mathbf{R W}^{\mathbf{1}}$ only. Two hundred extra grams of glucose were taken daily in all studies, except on day 14 of study $\mathrm{RW}^{2}$ when only $78 \mathrm{gm}$. were taken. Distilled water was allowed ad lib.

External balances of water were calculated from the weight of the diet, the measured fluid intake, the weight lost in excreta, the urine volume, the changes in body

\footnotetext{
4 These products were supplied by Mead Johnson and Co., Evansville, Indiana.
} 


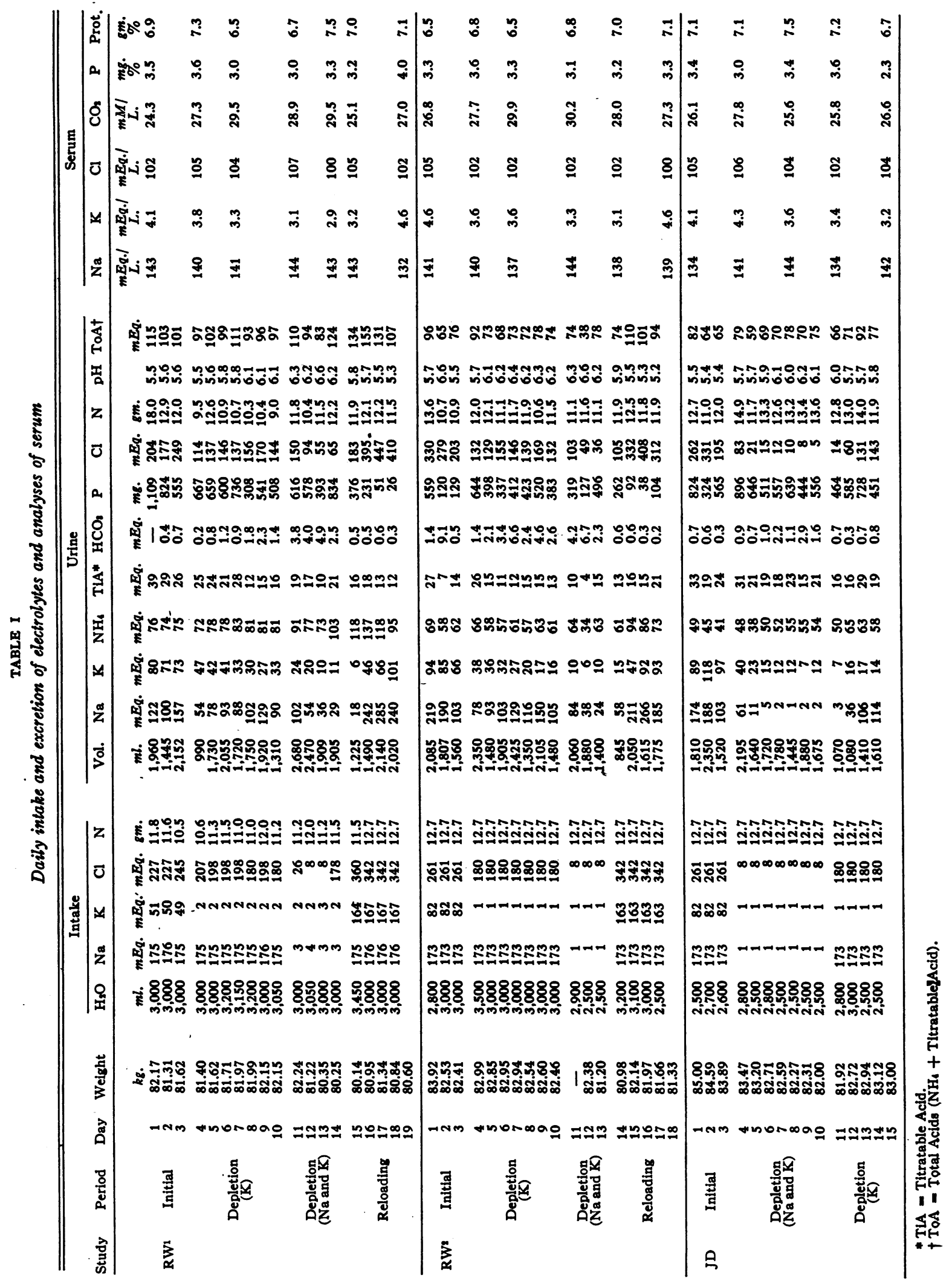


weight, and the water of oxidation of foodstuffs (1). Other balance data were calculated by methods previously reported from this department $(7,8)$ and by Darrow (9). No account was taken of electrolyte lost in the blood samples drawn and in the sweat.

Inorganic phosphorus was determined by the method of Fiske and Subbarow (10), modified for use with the photoelectric colorimeter; creatinine by the method of Hare (11) ; fecal chloride by the open Carius method (12) ; urine, fecal, and food nitrogen by the macroKjeldahl method (13); urine $\mathrm{pH}$ and titratable acidity were determined with the Cambridge Research Model $\mathrm{pH}$-meter, urine being titrated to $\mathrm{pH}$ 7.4. In preparing food and feces for the determination of sodium and potassium, the "wet" ashing method was used (14) and determinations were made on the flame photometer. Serum and urine sodium, potassium, and chloride, and serum carbon dioxide and proteins were determined by methods previously reported from this department (15, 16). Urine ammonia was determined by the method of Conway (17) and urine carbon dioxide by the Van Slyke manometric method (18).

\section{RESULTS}

The results of the analyses of serum are shown in Table I. In all studies concentrations of potassium in the serum fell as potassium depletion developed. During the Depletion $(K)$ periods of studies $\mathrm{RW}^{1}$ and $\mathrm{RW}^{2}$, the hypokalemia was associated with moderate increases in concentrations of bicarbonate. The highest concentrations reached were $29.5 \mathrm{mEq}$. per $\mathrm{L}$. and $30.2 \mathrm{mEq}$. per L., respectively. This effect was abolished in study $\mathrm{RW}^{1}$ by the ingestion of $9 \mathrm{gm}$. of ammonium chloride on day 14 of that study, and in study $\mathrm{RW}^{2}$ was modified by the the restriction of sodium intake in the Depletion ( $\mathrm{Na}$ and $\mathrm{K}$ ) period (days 11 and 14). During the Reloading periods serum potassium concentrations returned to normal values in both studies.

In study JD the hypokalemia induced in the Depletion ( $\mathrm{Na}$ and $\mathrm{K}$ ) period was not accompanied by an increase in serum bicarbonate (days 4 to 11), nor did this occur when sodium was returned to the diet in the Depletion (K) period (days 11 to 15 ), although serum potassium continued to fall.

Serum inorganic phosphorus concentrations did not vary consistently.

The daily excretion of electrolytes and the changes of urinary $\mathrm{pH}$ and body weight are shown in Table I. When potassium was withdrawn from the diet its excretion fell sharply at first but shortly approached a more or less steady rate. In $\mathrm{RW}^{\mathbf{1}}$ after three days of depletion it had fallen from $73 \mathrm{mEq}$. per day to $33 \mathrm{mEq}$., where it remained approximately for four days. In $\mathrm{RW}^{2}$ it fell somewhat more slowly from $66 \mathrm{mEq}$., but seemed to be flattening out in the last three days to between 20 and $16 \mathrm{mEq}$. In both experiments withdrawal of sodium was attended by a further reduction of potassium excretion. Although the total quantities of potassium in the urine were small, the breaks in the excretion curve when sodium was withdrawn are sharp enough to make them significant. Their significance is enhanced by the results of experiment JD. In this experiment the initial simultaneous withdrawal of sodium and potassium resulted in a greater and more rapid reduction of potassium excretion than did withdrawal of potassium alone in the other experiments. After the first three days the excretion had fallen to $12 \mathrm{mEq}$. per day and for five days it varied from 12 to $7 \mathrm{mEq}$. When sodium was again given it rose to $17 \mathrm{mEq}$. At no time in any of these periods was the concentration of potassium in the urine less than that in the serum.

The most outstanding features of the Depletion periods were that the urine became more alkaline and the excretion of bicarbonate tended to rise. This was true even in study JD in which serum carbon dioxide did not increase. The excretion of ammonia and titratable acid did not change significantly during the Depletion periods, but during the Reloading periods of studies $R W^{1}$ and and $\mathrm{RW}^{2}$ ammonia excretion increased, resulting in an increased output of Total Acid (ammonia plus titratable acid). The administration of ammonium chloride on day 14 of study $\mathrm{RW}^{1}$ increased ammonia excretion on that day but had no discernible effect on potassium excretion.

During the Depletion (K) periods of studies $\mathrm{RW}^{1}$ and $\mathrm{RW}^{2}$ sodium and chloride excretion decreased slightly. The balance data show that these ions were retained in the body in those periods (Table II).

Phosphorus excretion decreased markedly during the Reloading periods of studies $\mathrm{RW}^{1}$ and $\mathrm{RW}^{2}$.

The external and internal balance data are shown in Table II. Fecal losses were taken into account in calculating the external balances of 
TABLE II

Balances of water and electrolytes

\begin{tabular}{|c|c|c|c|c|c|c|c|c|c|c|c|c|c|}
\hline \multirow[b]{2}{*}{ Study } & \multirow[b]{2}{*}{ Period } & \multirow{2}{*}{$\begin{array}{c}\text { Dura- } \\
\text { tion } \\
\end{array}$} & \multicolumn{5}{|c|}{ External } & \multicolumn{3}{|c|}{ Extracellular } & \multicolumn{3}{|c|}{ Intracellular } \\
\hline & & & $\mathrm{H}_{8} \mathrm{O}$ & $\mathrm{Na}$ & $\mathbf{K}$ & $\mathrm{Cl}$ & $\mathrm{N}$ & $\mathrm{H}_{8} \mathrm{O}$ & $\mathrm{Na}$ & $\mathbf{K}$ & $\mathrm{H}_{2} \mathrm{O}$ & $\mathrm{Na}$ & $\mathbf{K}$ \\
\hline \multirow[t]{3}{*}{$\mathbf{R} \mathbf{W}^{\mathbf{1}}$} & \multirow{3}{*}{$\begin{array}{c}\text { Initial } \\
\text { Depletion } \\
\text { (K) } \\
\text { Depletion } \\
\text { (Na and K) } \\
\text { Reloading }\end{array}$} & $\begin{array}{c}\text { Days } \\
3 \\
7\end{array}$ & $\begin{array}{c}L . \\
-1.0 \\
+0.6\end{array}$ & $\begin{array}{l}m E q . \\
+146 \\
+569\end{array}$ & $\begin{array}{l}m E q . \\
-52 \\
-267\end{array}$ & $\begin{array}{l}m E q . \\
+\quad 69 \\
+351\end{array}$ & $\begin{array}{c}g m . \\
-9.4 \\
+2.5\end{array}$ & $\begin{array}{c}L . \\
0 \\
+2.6\end{array}$ & $\begin{array}{c}m E q . \\
-49 \\
+444\end{array}$ & $\begin{array}{l}m E q . \\
-5 \\
-5\end{array}$ & $\begin{array}{c}L . \\
-1.0 \\
-2.0\end{array}$ & $\begin{array}{c}m E q . \\
+195 \\
+125\end{array}$ & $\begin{array}{l}m E q . \\
-47 \\
-262\end{array}$ \\
\hline & & 4 & -2.1 & -235 & -63 & -154 & -1.9 & -1.0 & -146 & +1 & -1.1 & -89 & -64 \\
\hline & & 4 & +0.4 & -89 & +431 & -52 & +0.3 & +0.2 & -172 & +26 & +0.2 & +83 & +405 \\
\hline \multirow[t]{3}{*}{$R W^{2}$} & \multirow{3}{*}{$\begin{array}{c}\text { Initial } \\
\text { Depletion } \\
\text { (K) } \\
\text { Depletion } \\
\text { (Na and K) } \\
\text { Reloading }\end{array}$} & $\begin{array}{l}3 \\
7\end{array}$ & $\begin{array}{l}-1.0 \\
-0.8\end{array}$ & $\begin{array}{r}0 \\
+417\end{array}$ & $\begin{array}{l}-19 \\
-226\end{array}$ & $\begin{array}{r}33 \\
+249\end{array}$ & $\begin{array}{l}+1.5 \\
+4.5\end{array}$ & $\begin{array}{l}+0.3 \\
+2.2\end{array}$ & $\begin{array}{r}+94 \\
+409\end{array}$ & $\begin{array}{l}-13 \\
+2\end{array}$ & $\begin{array}{l}-1.3 \\
-3.0\end{array}$ & $\begin{array}{r}-94 \\
+\quad 8\end{array}$ & $\begin{array}{l}-6 \\
-228\end{array}$ \\
\hline & & 3 & -1.3 & -149 & -40 & -165 & +3.0 & -1.8 & -353 & -8 & +0.5 & +204 & -32 \\
\hline & & 4 & +0.5 & -47 & +376 & +201 & -0.2 & +2.3 & +347 & +38 & -1.8 & -394 & +338 \\
\hline \multirow[t]{2}{*}{ JD } & \multirow{2}{*}{$\begin{array}{c}\text { Initial } \\
\text { Depletion } \\
\text { (Na and K) } \\
\text { Depletion } \\
\text { (K) }\end{array}$} & $\begin{array}{l}3 \\
7\end{array}$ & $\begin{array}{l}-1.4 \\
-1.7\end{array}$ & $\begin{array}{l}+38 \\
-84\end{array}$ & $\begin{array}{l}-70 \\
-113\end{array}$ & $\begin{array}{l}-20 \\
-108\end{array}$ & $\begin{array}{l}-0.1 \\
-6.7\end{array}$ & $\begin{array}{l}-0.3 \\
-0.2\end{array}$ & $\begin{array}{l}-126 \\
-194\end{array}$ & $\begin{array}{l}+2 \\
-15\end{array}$ & $\begin{array}{l}-1.1 \\
-1.5\end{array}$ & $\begin{array}{l}+164 \\
+110\end{array}$ & $\begin{array}{l}-72 \\
-98\end{array}$ \\
\hline & & 4 & +1.2 & +421 & -49 & +357 & -2.8 & +3.0 & +547 & +4 & -1.8 & -126 & -53 \\
\hline
\end{tabular}

electrolytes and nitrogen. The external balances of potassium have been corrected for nitrogen. Negative external balance of potassium occurred during the Depletion periods. The major part of these losses was provided from cell potassium. When sodium was present in the diet, potassium depletion resulted in marked retention of sodium in the extracellular compartment and expansion of this compartment in all studies (Depletion (K) periods). The expansion of the extracellular space was due chiefly to the transfer of cell water. Restriction of sodium intake prevented, or tended to abolish, these effects (Depletion ( $\mathrm{Na}$ and $\mathrm{K}$ ) periods). During the Reloading periods in studies $\mathrm{RW}^{1}$ and $\mathrm{RW}^{2}$ large positive intracellular balances of potassium occurred.

The clearances of creatinine did not change significantly in any of the studies. The electrocardiographic records remained normal. Each subject experienced one attack of diarrhea in the Depletion ( $\mathrm{Na}$ and $\mathrm{K}$ ) periods, and the boredom of the diet produced irritability, fatigue, and difficulty in concentration.

\section{DISCUSSION}

Deficits of potassium amounting to $330 \mathrm{mEq}$, $266 \mathrm{mEq}$., and $162 \mathrm{mEq}$., respectively, were induced in the three studies. The total exchangeable potassium of the body, which probably accurately reflects the metabolically active potassium pool (19), has been estimated to have a mean value of $46.3 \mathrm{mEq}$. per $\mathrm{kg}$. of body weight (20). If this estimate is correct the subjects lost approximately 9 per cent, 7 per cent, and 4 per cent of their exchangeable body potassium. While much larger deficits have been observed in experimental studies in which depletion was induced by the ingestion of an ion-exchange resin (21), our results are comparable to those that others have obtained by dietary restriction $(1,2)$.

Since potassium losses in the feces were small, the deficits were due almost entirely to losses in the urine. The longest Depletion period for potassium was 11 days. While the importance of renal leakage in determining depletion of body potassium has been stressed (4), the kidney is capable of conserving potassium to a considerable extent (5). This conservative process is promoted by restriction of sodium. This is best illustrated in study $\mathrm{RW}^{2}$, where the rate of excretion averaged $82 \mathrm{mEq}$. per day in the Initial period, and $9 \mathrm{mEq}$. per day on the last three days of potassium and sodium restriction. None of the subjects achieved potassium balance. The difference in the renal capacity to conserve sodium and potassium is illustrated by the Depletion ( $\mathrm{Na}$ and $\mathrm{K}$ ) period of study JD. On the fourth day of that period sodium had virtually disappeared from the urine, while considerable losses of potassium continued throughout the study. 
It has been assumed that the small increase in serum bicarbonate recorded during the Depletion (K) periods of studies $\mathrm{RW}^{1}$ and $\mathrm{RW}^{2}$ represent a metabolic alkalosis, since it has been shown that in similar circumstances the $\mathrm{CO}_{2}$ tension of alveolar air does not increase (1). The failure of alkalosis to develop during the Depletion ( $\mathrm{Na}$ and $\mathrm{K}$ ) period of study JD may have been due to the smaller losses of potassium that occurred in this study, or to the depletion of body sodium and potassium (Table II). Darrow, Schwartz, Iannucci, and Coville have demonstrated the dependence of serum bicarbonate on cell composition (6). They showed that bicarbonate varied inversely with cell potassium and directly with cell sodium; and, furthermore, that for every 3 potassium ions discharged from the cells 2 sodium ions were gained. It has been suggested that hydrogen may replace the one-third of potassium not "covered" by sodium (22). This theory envisages that the extracellular alkalosis so determined is balanced by an intracellular acidosis. An alternative explanation of the alkalosis of hypokalemia was advanced following the demonstration by Berliner, Kennedy, and Orloff (23) that potassium and hydrogen are in competition for a common component of the distal renal tubular cation exchange mechanism. It was postulated that the alkalosis might be due to increased hydrogen excretion. The data presented here show that during the development of the alkalosis associated with potassium depletion the urine became more alkaline, with increased excretion of bicarbonate and no increase in the excretion of acid. We feel that this is in direct contravention of the theory of the renal origin of the alkalosis, the development of which must involve shifts by way of the cellular ion-exchange mechanism. Other investigators have arrived at the same conclusion (1).

Potassium depletion resulted in the retention of salt and water in the extracellular space. Correlation between creatinine clearance and these phenomena was not demonstrated. There is no reason for excluding the possibility of some remote effect of the cellular exchanges on reabsorption of sodium by the kidney. The prompt reaction to the deprivation of sodium favors such a remote origin rather than a purely renal response.

The sharp falls in the urinary excretion of phosphorus during the Reloading periods in studies
$\mathrm{RW}^{1}$ and $\mathrm{RW}^{2}$ may indicate that phosphorus was being retained in the body at those times. Since the serum inorganic phosphorus levels did not change consistently, some phosphorus may have entered cells with potassium. Retention of phosphorus during the reloading of potassium-depleted subjects has been described by other workers $(1,2)$.

\section{SUM MARY}

1. In the normal human, restriction of potassium intake leads to a deficiency of the ion, chiefly due to urinary losses, although the kidney is able to conserve potassium to some extent.

2. Conservation of potassium is promoted by restriction of sodium.

3. Withdrawal of potassium is accompanied by a metabolic alkalosis and the production of a more alkaline urine.

4. When sodium is present in the diet, potassium depletion results in the retention of salt and water in the extracellular space. These effects are prevented or abolished by sodium restriction.

\section{ACKNOWLEDGMENT}

The authors would like to thank Dr. John P. Peters for help with the manuscript and Mrs. Marija Kompare for technical assistance.

\section{REFERENCES}

1. Black, D. A. K., and Milne, M. D., Experimental potassium depletion in man. Clin. Sc., 1952, 11, 397.

2. Blahd, W. H., and Bassett, S. H., Potassium deficiency in man. Metabolism, 1953, 2, 218.

3. Reimer, A., Schoch, H. K., and Newburgh, L. H., Certain aspects of potassium metabolism. J. Am. Dietet. A., 1951, 27, 1042.

4. Tarail, R., and Elkinton, J. R., Potassium deficiency and the role of the kidney in its production. $J$. Clin. Invest., 1949, 28, 99.

5. Fourman, P., The ability of the normal kidney to conserve potassium. Lancet, 1952, 1, 1042.

6. Darrow, D. C., Schwartz, R., Iannucci, J. F., and Coville, F., The relation of serum bicarbonate concentration to muscle composition. J. Clin. Invest., 1948, 27, 198.

7. Elkinton, J. R., and Winkler, A. W., Transfers of intracellular potassium in experimental dehydration. J. Clin. Invest., 1944, 23, 93.

8. Elkinton, J. R., Winkler, A. W., and Danowski, T. S., Transfers of cell sodium and potassium in experimental and clinical conditions. J. Clin. Invest., 1948, 27, 74. 
9. Darrow, D. C., The retention of electrolyte during recovery from severe dehydration due to diarrhea. J. Pediat., 1946, 28, 515.

10. Fiske, C. H., and Subbarow, Y., The colorimetric determination of phosphorus. J. Biol. Chem., 1925, 66, 375.

11. Hare, R. S., Endogenous creatinine in serum and urine. Proc. Soc. Exper. Biol. \& Med., 1950, 74, 148.

12. Peters, J. P., and Van Slyke, D. D., Quantitative Clinical Chemistry. Vol. 2, Methods. Baltimore, The Williams \& Wilkins Co., 1932, p. 835.

13. Peters, J. P., and Van Slyke, D. D., Quantitative Clinical Chemistry. Vol. 2, Methods. Baltimore, The Williams \& Wilkins Co., 1932, p. 516.

14. Hald, P. M., Determinations with flame photometer in Methods in Medical Research, ed. by M. B. Visscher, Vol. IV, Chicago, Year Book Publishers, Inc., 1951, pp. 94-5.

15. Hald, P. M., Determinations with flame photometer in Methods in Medical Research, ed. by M. B. Visscher, Vol. IV, Chicago, Year Book Publishers, Inc., 1951, p. 79.

16. Elkinton, J. R., and Taffel, M., Prolonged water deprivation in the dog. J. Clin. Invest., 1942, 21, 787.
17. Conway, E. J., Microdiffusion Analysis and Volumetric Error. Revised, London, C. Lockwood, 1947, p. 357.

18. Peters, J. P., and Van Slyke, D. D., Quantitative Clinical Chemistry. Vol. 2, Methods. Baltimore, The Williams \& Wilkins Co., 1932, p. 290.

19. Schwartz, W. B., and Relman, A. S., Metabolic and renal studies in chronic potassium depletion resulting from overuse of laxatives. J. Clin. Invest., 1953, 32, 258.

20. Corsa, L., Jr., Olney, J. M., Jr., Steenburg, R. W., Ball, M. R., and Moore, F. D., The measurement of exchangeable potassium in man by isotope dilution. J. Clin. Invest., 1950, 29, 1280.

21. Fourman, P., Depletion of potassium induced in man with an exchange resin. Clin. Sc., 1954, 13, 93.

22. Cooke, R. E., Segar, W. E., Cheek, D. B., Coville, F. E., and Darrow, D. C., The extrarenal correction of alkalosis associated with potassium deficiency. J. Clin. Invest., 1952, 31, 798.

23. Berliner, R. W., Kennedy, T. J., Jr., and Orloff, J., Relationship between acidification of the urine and potassium metabolism. Effect of carbonic anhydrase inhibition on potassium excretion. Am. J. Med., 1951, 11, 274. 